\title{
Variable speed wind turbine for maximum power capture using adaptive fuzzy integral sliding mode control
}

\author{
Saravanakumar RAJENDRAN, Debashisha JENA (ه)
}

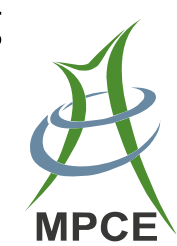

\begin{abstract}
This paper presents a nonlinear control approach to variable speed wind turbine (VSWT) with a wind speed estimator. The dynamics of the wind turbine (WT) is derived from single mass model. In this work, a modified Newton Raphson estimator has been considered for exact estimation of effective wind speed. The main objective of this work is to extract maximum energy from the wind at below rated wind speed while reducing drive train oscillation. In order to achieve the above objectives, VSWT should operate close to the optimal power coefficient. The generator torque is considered as the control input to achieve maximum energy capture. From the literature, it is clear that existing linear and nonlinear control techniques suffer from poor tracking of WT dynamics, increased power loss and complex control law. In addition, they are not robust with respect to input disturbances. In order to overcome the above drawbacks, adaptive fuzzy integral sliding mode control (AFISMC) is proposed for VSWT control. The proposed controller is tested with different types of disturbances and compared with other nonlinear controllers such as sliding mode control and integral sliding mode control. The result shows the better performance of AFISMC and its robustness to input disturbances. In this paper, the discontinuity in integral sliding mode controller is smoothed by using hyperbolic tangent function, and the sliding gain is adapted using a fuzzy technique which makes the controller more robust.
\end{abstract}

CrossCheck date: 29 May 2014

Received: 15 February 2014/ Accepted: 22 April 2014/Published Online: 26 June 2014

(C) The Author(s) 2014. This article is published with open access at Springerlink.com

S. RAJENDRAN, D. JENA, National Institute of Technology

Karnataka, Surathkal, India

$(\bowtie)$ e-mail: bapu4002@gmail.com
Keywords Variable speed wind turbine, Integral sliding mode controller (ISMC), Sliding mode control (SMC), Adaptive fuzzy integral sliding mode control (AFISMC)

\section{Introduction}

Because of the power crises and environmental issues, renewable energy sources play a vital role in energy market. Among all renewable energy sources, wind energy is one of the rapidly growing energy technology and has its own benefits such as pollution free, clean and environmental friendly. In recent years, due to the advance in drive technology and grid interconnection control, the production of wind power is increased. Generally, WT has two different types: fixed speed WT (FSWT) and variable speed WT (VSWT). The main advantages of VSWT over FSWT is that, the annual power production is increased by $5 \%-$ $10 \%$, and reduction in mechanical stress and power fluctuations $[1,2]$. Generally, wind speed is classified into two types: below and above rated wind speed. Accordingly, the WT control is classified into two types: torque control and pitch control. At below rated wind speed, the main objective of the WT is, to maximize the wind energy capture from the wind by rotating the WT rotor at optimal rotor speed, which is derived from effective wind speed. At above rated speed, the main objective of the WT is to control the pitch angles which correspond to the reference power. In literature, some of the authors have discussed the control of WT with the assumption that the effective wind speed is available. In [3], a fuzzy controller was used to maximize the power capture, improve the efficiency, and the controller was found to be more robust to the wind gust and oscillatory torque. In [4], control algorithm based on fuzzy logic control (FLC) tracks the maximum power by controlling the WT rotor speed without estimating the effective wind speed. In WT control, several literatures 


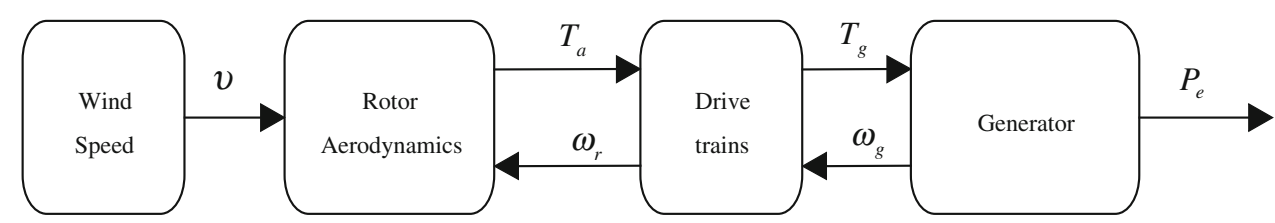

Fig. 1 Schematic of WT

reported either to estimate or to calculate the effective wind speed with WT control. In [5], the rotor speed and aerodynamic torque are estimated by the input and state based estimation with the known pitch angle, the effective wind speed is calculated by the inversion of the static aerodynamic model. In [6-8], Kalman filter is used to estimate rotor speed and aerodynamic torque, and finally the effective wind speed is calculated using Newton Raphson. For the single mass model given in $[6,7]$ and two mass model given in [8], nonlinear controllers such as nonlinear static state feedback with estimator and nonlinear dynamic state feedback with estimator (NDSFE) are used to control the WT at below rated wind speed. For both the controllers, the wind speed is estimated using Newton Raphson. In [9], calculation of effective wind speed is achieved by the particle filter, and FLC is used to control the WT at below rated wind speed. In [10-12], the SMC based controllers are applied to the WT without estimating the effective wind speed. References [10, 11] discussed higher order sliding mode control (HSMC) of WT at below and above rated speed and concluded that HSMC is more robust with respect to parameter uncertainty of the WT. In [12, 15], conventional SMC based control with adaptive sliding gain is used to control the WT where the sliding gain is varied by an adaptation algorithm.

The objective of this work is to maximize the energy capture from the wind with reduced oscillation in drive train. Modified Newton Raphson (MNR) is used to estimate the effective wind speed. A comparison of WT efficiency, with respect to maximum power capture, reduced transient load on drive train, and robustness to input disturbances is done by using different control algorithms. It is observed that, AFISMC is achieving the above objectives with more robustness to different types of input disturbances. The results are validated for different wind speed profile.

\section{WT model}

A WT is a device which converts the kinetic energy of the wind into electric energy. Simulation complexity of the WT purely depends on the type of control objectives. In case of WT modeling, complex simulators are required to verify the dynamic response of multiple components and aerodynamic loading. Generally, dynamic loads and interaction of large components are verified by the aero elastic simulator. For designing a WT controller, instead of going with complex simulator, the design objective can be achieved by using simplified mathematical model. In this work, WT model is described by the set of nonlinear ordinary differential equation with limited degree of freedom. This paper describes the control law for a simplified mathematical model with the objective of optimal power capture at below rated wind speed and reduced oscillation of the drive train. The proposed controller is tested with different wind profiles in the presence of different types of input disturbances.

Generally, VSWT system consists of the following components: aerodynamics, drive trains, and generator. The schematic of WT is shown in Fig. 1.

Equation (1) gives the nonlinear expression for aerodynamic power capture by the rotor

$P_{a}=\frac{1}{2} \rho \pi R^{2} C_{P}(\lambda, \beta) v^{3}$

where $R$ is the radius; $\rho$ is the air density; $\omega_{r}$ is the rotor speed ( $\mathrm{rad} / \mathrm{s}) ; C_{P}$ is the power coefficient of the WT; and $v$ is the wind speed $(\mathrm{m} / \mathrm{s})$.

From (1), it is clear that the aerodynamic power $\left(P_{a}\right)$ is directly proportional to the cube of the wind speed. The power coefficient $C_{P}$ is the function of blade pitch angle $(\beta)$ and tip speed ratio $(\lambda)$. The tip speed ratio is defined as ratio between linear tip speed and wind speed.

$\lambda=\frac{\omega_{r} R}{v}$

Generally, wind speed is stochastic with respect to time. Because this tip speed ratio gets affected, it will lead to the variation in power coefficient. The relationship between aerodynamic torque $\left(T_{a}\right)$ and the aerodynamic power is given in (3).

$P_{a}=T_{a} \omega_{r}$

$T_{a}=\frac{1}{2} \rho \pi R^{3} C_{q}(\lambda, \beta) v^{2}$

where $C_{q}$ is the torque coefficient given as

$C_{q}(\lambda, \beta)=\frac{C_{P}(\lambda, \beta)}{\lambda}$

Substituting (5) in (4), we get 
Table 1 Coefficients values

\begin{tabular}{ll}
\hline$a_{0}=0.1667$ & $a_{3}=-0.01617$ \\
$a_{1}=-0.2558$ & $a_{4}=0.00095$ \\
$a_{2}=0.115$ & $a_{5}=-2.05 \times 10^{-5}$ \\
\hline
\end{tabular}

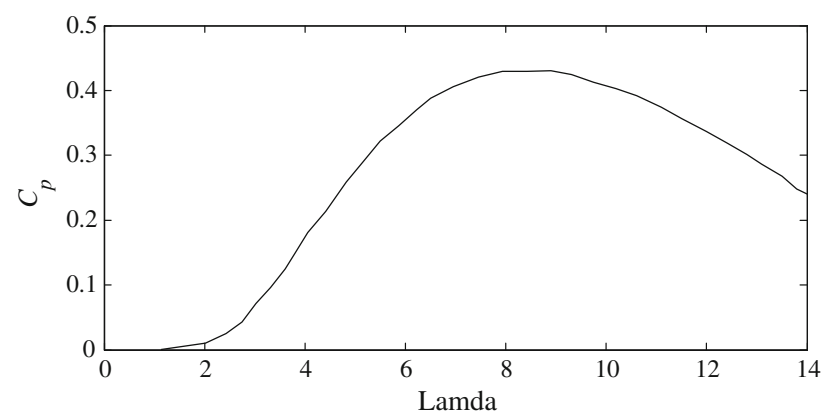

Fig. $2 C_{p}$ vs $\lambda$ curve

$T_{a}=\frac{1}{2} \rho \pi R^{3} \frac{C_{P}(\lambda, \beta)}{\lambda} v^{2}$

In above equation, the nonlinear term is $C_{p}$ which can be approximated by the $5^{\text {th }}$ order polynomial given in (7).

$$
\begin{aligned}
C_{P}(\lambda) & =\sum_{n=0}^{5} a_{n} \lambda^{n} \\
& =a_{0}+\lambda a_{1}+\lambda^{2} a_{2}+\lambda^{3} a_{3}+\lambda^{4} a_{4}+\lambda^{5} a_{5}
\end{aligned}
$$

where $a_{0}$ to $a_{5}$ are the WT power coefficient. The values of approximated coefficients are given in Table 1. Figure 2 shows the $C_{p}$ versus $\lambda$ curve.

Figure 3 shows the two mass model of the WT. Equation (8) represents dynamics of the rotor speed $\omega_{r}$ with rotor inertia $J_{r}$ driven by the aerodynamic torque $\left(T_{a}\right)$.

$J_{r} \dot{\omega}_{r}=T_{a}-T_{l s}-K_{r} \omega_{r}$

Breaking torque acting on the rotor is low speed shaft torque $\left(T_{l s}\right)$ which can be derived by using stiffness and damping factor of the low speed shaft given in (9).
$T_{l s}=B_{l s}\left(\theta_{r}-\theta_{l s}\right)+K_{l s}\left(\omega_{r}-\omega_{l s}\right)$

Equation (10) represents dynamics of the generator speed $\omega_{g}$ with generator inertia $J_{g}$ driven by the high speed shaft torque $\left(T_{h s}\right)$ and braking electromagnetic torque $\left(T_{e m}\right)$.

$J_{g} \dot{\omega}_{g}=T_{h s}-K_{g} \omega_{g}-T_{e m}$

Gearbox ratio is defined as

$n_{g}=\frac{T_{l s}}{T_{h s}}=\frac{\omega_{g}}{\omega_{l s}}$

Transforming the generator side dynamics into the low speed shaft side, we will get

$n_{g}^{2} J_{g} \dot{\omega}_{g}=T_{l s}-n_{g} K_{g} \omega_{g}-n_{g} T_{e m}$

If a perfectly rigid low-speed shaft is assumed, the dynamics of the rotor characteristics of a single mass WT model can be expressed by a first order differential equation given as

$J_{t} \dot{\omega}_{r}=T_{a}-T_{g}-K_{t} \omega_{r}$

where

$J_{t}=J_{r}+n_{g}^{2} J_{g}$

$K_{t}=K_{r}+n_{g}^{2} K_{g}$

$T_{g}=n_{g} T_{e m}$

\section{Control objectives}

Generally, WT is classified into two types: fixed and variable speed WT. Variable speed WT has more advanced and flexible operation than fixed speed WT. Operating regions in variable speed WT are divided in to three types. Figure 4 shows the various operating region in variable speed WT. Region 1 represents the wind speed below the cut in wind speed. Region 2 represents the wind speed between cut in and cut out. In this region, the main objective is to maximize the energy capture from the wind with reduced oscillation on the drive train.

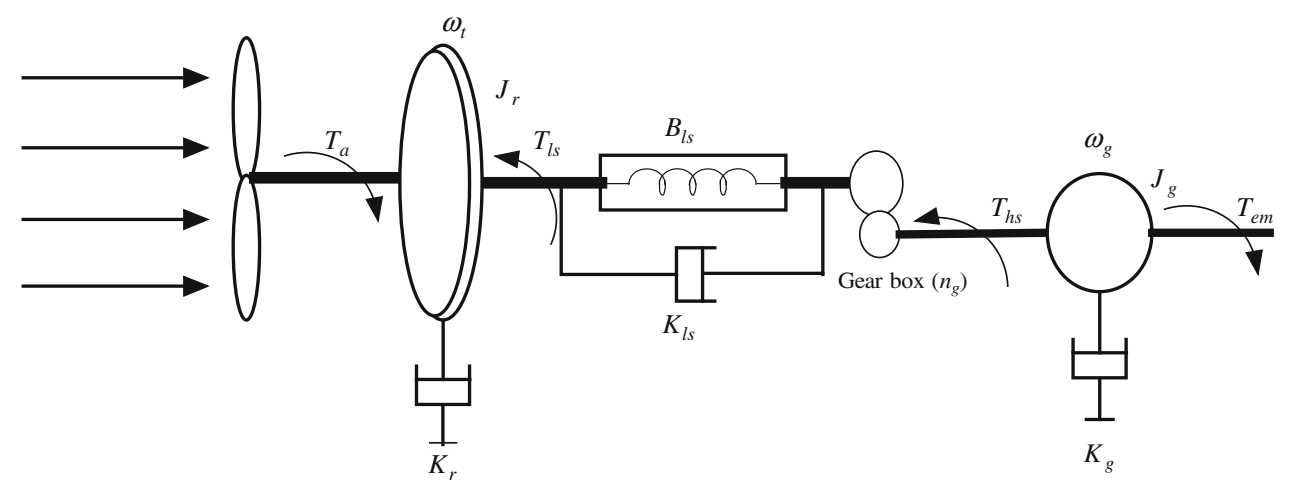

Fig. 3 Two mass model of the WT [8] 


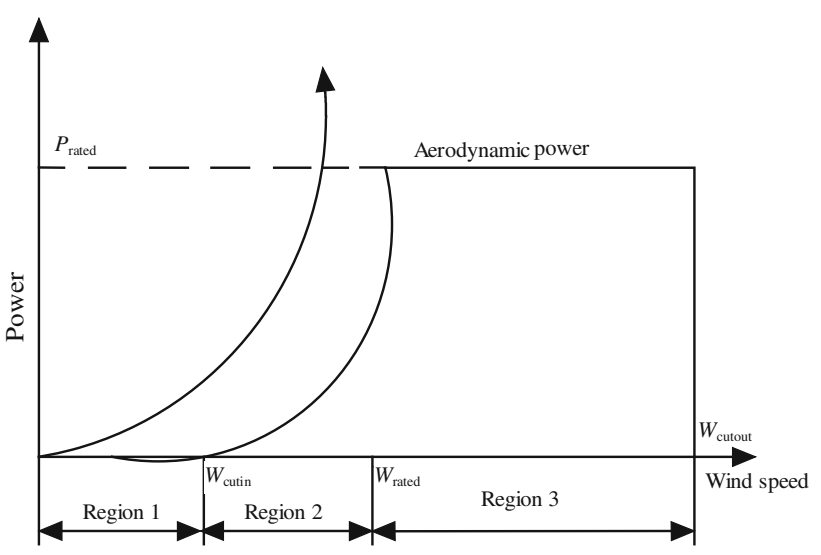

Fig. 4 Power operating region of wind turbines

Region 3 describes the wind speed above the cut out speed. In this region, pitch controller is used to maintain the WT at its rated power.

To achieve the above objective (Region 2 ), the blade pitch angle $\left(\beta_{\text {opt }}\right)$ and tip speed ratio $\left(\lambda_{\text {opt }}\right)$ are set to be its optimal value. In order to achieve the optimal tip speed ratio, the rotor speed must be adjusted to the reference/optimal rotor speed $\left(\omega_{\text {ropt }}\right)$ by adjusting the generator torque $\left(T_{g}\right)$. Equation (17) defines the reference/optimal rotor speed $\left(\omega_{\text {ropt }}\right)$.

$\omega_{\text {ropt }}=\frac{\lambda_{\text {opt }} v}{R}$

Figure 5 shows the WT control scheme. It is clear that WT has two control loops: inner and outer loop. The inner control loop consists of electrical generator with power converters. The outer loop having the aero turbine control which gives the reference to the inner loop is shown in Fig. 5. In this paper, we made an assumption that, the inner loop is well controlled.

\subsection{Wind speed estimator}

The aero dynamic torque is approximated with $5^{\text {th }}$ order polynomial given in (7). It is assumed that rotor speed measurement is available. Estimation of effective wind speed depends on aerodynamic torque and rotor speed with the pitch angle at optimal value.

$F(v)=T_{a}-\frac{1}{2} \rho \pi R^{3} \frac{C_{P}(\lambda)}{\lambda} v^{2}$

The MNR algorithm is used to solve the effective wind speed (v) from (18). This equation has unique solution at below rated region. With known $v$, the optimal rotor speed $\omega_{\text {ropt }}$ is calculated by using (17).

\subsection{Sliding mode control}

To achieve the maximum power at below rated wind speed, sliding mode based torque control is proposed in [12]. The main objective of this controller is to track the reference rotor speed $\omega_{\text {ref }}$ for maximum power extraction. In conventional sliding mode control, sliding surface generally depends on error, and derivative of the error signal is given in (19).

$S(t)=\left(\lambda+\frac{d}{d t}\right)^{n-1} e(t)$

where $\lambda$ is the positive constant and $n$ is the order of the uncontrolled system.

For speed control, a sliding surface is defined as

$S(t)=\omega_{r}(t)-\omega_{r e f}(t)$

The reference rotor speed has defined in (17). Taking the time derivative of (20), we get

$\dot{S}(t)=\dot{\omega}_{r}(t)-\dot{\omega}_{r e f}(t)$

Substituting $\dot{\omega}_{r}$ from (13) into (21), we get

$\dot{S}=\frac{1}{J_{t}} T_{a}-\frac{K_{t}}{J_{t}} \omega_{r}-\frac{1}{J_{t}} T_{g}-\dot{\omega}_{r e f}$

Stability of SMC can be evaluated by using Lyapunov candidate function given in (23):

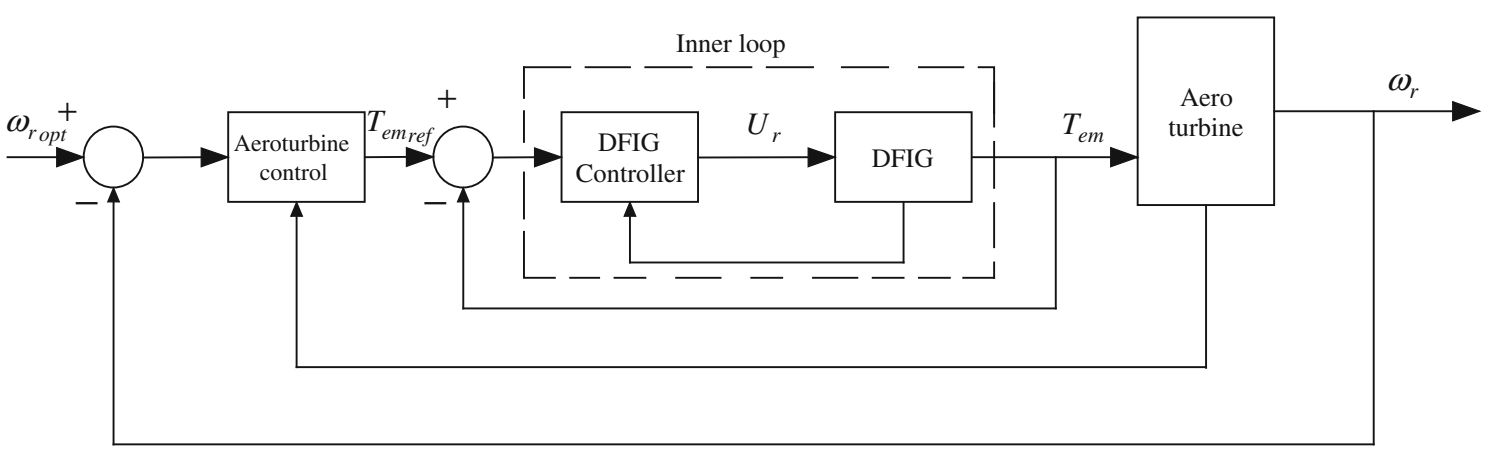

Fig. 5 WT control scheme 
$V=\frac{1}{2} S^{2}$

Taking the time derivative of the above equation, then

$\dot{V}=S \dot{S}=S\left[\frac{1}{J_{t}} T_{a}-\frac{K_{t}}{J_{t}} \omega_{r}-\frac{1}{J_{t}} T_{g}-\dot{\omega}_{r e f}\right]$

if $\dot{V}$ is negative definite

$\frac{1}{J_{t}} T_{a}-\frac{K_{t}}{J_{t}} \omega_{r}-\frac{1}{J_{t}} T_{g}-\dot{\omega}_{r e f}\left\{\begin{array}{cc}<0 & \text { for } S>0 \\ >0 & \text { for } S<0\end{array}\right\}$

Stability of the controller is guaranteed if the torque control law satisfies (26).

$T_{g}\left\{\begin{array}{cc}<T_{a}-K_{t} \omega_{r}-J_{t} \dot{\omega}_{r e f} & \text { for } S>0 \\ >T_{a}-K_{t} \omega_{r}-J_{t} \dot{\omega}_{r e f} & \text { for } S<0\end{array}\right\}$

Generally, the SMC have two parts: equivalent control $U_{e q}$ and switching control $U_{s w}$. Combining these two controls for minimizing the tracking error, the control input can be expressed as

$U(t)=U_{e q}(t)+U_{s w}(t)$

Finally, the torque control structure is given in (28) as

$T_{g}=T_{a}-K_{t} \omega_{r}-J_{t} \dot{\omega}_{r e f}+J_{t} k \operatorname{sign}(S)$

The major drawback in the signum function is that, it has the discontinued value between +1 and -1 due to which it introduces the chattering phenomenon. So the signum function is changed by a smooth hyperbolic tangent (tanh) function with boundary layer $(\varphi)$.

$T_{g}=T_{a}-K_{t} \omega_{r}-J_{t} \dot{\omega}_{r e f}+J_{t} k \tanh \left(\frac{S}{\varphi}\right)$

where $k$ is the sliding gain.

\subsection{Integral fuzzy sliding mode control}

To improve the sliding surface and overcome the steady state error, the integral action is included in the sliding surface [14]. An integral sliding surface is defined as

$S(t)=\left(\lambda+\frac{d}{d t}\right)^{n-1} e(t)+k_{i} \int_{0}^{\infty} e(t) d t$

where $k_{i}$ is the integral gain.

For first order $n=1$, then the sliding surface modified as

$S(t)=e(t)+k_{i} \int_{0}^{\infty} e(t) d t$

The major objective of the controller is that, the tracking error $e(t)$ should converge to zero. The stability of the controller is determined by using the Lyapunov candidate function given in (23) with $V(0)=0$ and $V(t)>0$ for $S \neq 0$.

By taking the time derivative of the (31), we get

$$
\begin{aligned}
& \dot{S}(t)=\dot{e}(t)+k_{i} e(t) \\
& \dot{V}=\dot{S} S=S\left[\frac{1}{J_{t}} T_{a}-\frac{K_{t}}{J_{t}} \omega_{r}-\frac{1}{J_{t}} T_{g}-\dot{\omega}_{r e f}+k_{i} e(t)\right]
\end{aligned}
$$

Generally, the SMC have two parts: equivalent control $U_{e q}$ and switching control $U_{s w}$. By combining these two controls, tracking error can be minimized, and we will get the total control as

$U(t)=U_{e q}+U_{s w}$

The Switching control is defined in two ways

$U_{s w}=k \operatorname{sign}\left(\frac{S}{\varphi}\right)$

or

$U_{s w}=k \tanh \left(\frac{S}{\varphi}\right)$

Finally, the torque control structure is given as

$T_{g}=T_{a}-K_{t} \omega_{r}-J_{t} \dot{\omega}_{r e f}+J_{t} k_{i} e(t)+J_{t} k \tanh \left(\frac{S}{\varphi}\right)$

3.4 Adaptive fuzzy integral sliding mode control (AFISMC)

In order to accommodate the input disturbances, the fixed gain $k$ in ISMC has been replaced by the variable gain which is achieved by AFISMC. The main aim of the AFISMC controller is to achieve robustness with respect to disturbances. In Fuzzy SMC, variable boundary layer $(\varphi)$ is a function of $S$ and $\dot{S}(t)$ [13]. In this problem, we need to avoid more tracking errors, in the presence of disturbance in the control input like generator torque $\left(T_{g}\right)$. Fuzzy logic (FL) is used to improve the performance of the controller as well as the system. FL is used to automatically adjust the variable gain based on sliding surface and derivative of the sliding surface. The input to the fuzzy controller is sliding surface and derivative of the sliding surface, and the output is variable gain. Equation (38) defines the control input for AFISMC.

$T_{g}=T_{a}-K_{t} \omega_{r}-J_{t} \dot{\omega}_{r e f}+J_{t} k_{i} e(t)+J_{t} k_{f u z z y} \tanh \left(\frac{S}{\varphi}\right)$

A variable sliding gain layer is introduced to smooth out the discontinuity which ensures reduced chattering effect. The condition $S=0$ indicates the tracking error is zero, and the switching control is also zero. But during simulation, it may not possible to achieve the tracking 
Table 2 Fuzzy rules $S, \dot{S}(t)$ and $k_{f u z z y}$

\begin{tabular}{llllll}
\hline U(t) & $\dot{S}(t)$ & & & & \\
\cline { 2 - 6 }$S(t)$ & NB & NS & Z & PS & PB \\
\hline NB & Z & NS & PS & NS & NS \\
NS & NS & PS & NS & NS & Z \\
Z & NB & NS & NB & PB & NS \\
PS & PS & PB & Z & NS & NS \\
PB & PS & PB & NS & PB & NS \\
\hline
\end{tabular}

error to zero because of high tracking dynamics in the reference signal. So the varying fuzzy sliding gain is introduced in the ISMC control.

The triangular membership function is used for both inputs and output fuzzy variables. The inputs are error and derivative of the error which is varying between the $\{-0.4$, $0.4\}$ and $\{-0.04,0.04\}$ respectively. The output variable is sliding gain which is varying between $\{0.006,0.2\}$. The fuzzy variables are defined in the rule base as \{NS (Negative Small), NB (Negative Big), Z (Zero), PS (Positive Small) and PB (Positive Big)\}. From the conventional SMC and ISMC, the knowledge of the sliding gain is obtained. With this knowledge, the fuzzy rules in Table 2 are initially derived by trial and error method. After obtained the rule base, the simulation is carried out and it is tuned appropriately as per the control objectives. Finally, the derived rule base is validated for different disturbances and different mean wind speed conditions. From the results, it is found that the rule base is optimal for achieving the given control objectives. A typical fuzzy control rule of the proposed AFISMC is expressed as: $R^{(i)}:: \mathrm{IF} S(t)$ is $H_{1}^{i}$ and $\dot{S}(t)$ is $H_{2}^{i}$ THEN $k_{f u z z y}$ is $M^{i}$ where $H_{1}^{i}$ and $H_{2}^{i}$ are the labels of the input fuzzy sets and $M^{i}$ is the labels of the output fuzzy sets, $i=1, \ldots, p$ represents the number of IF-THEN fuzzy rules. Table 2 explains the linguistic fuzzy rules for AFISMC. The fuzzy control surface of the output is shown in Fig. 6.

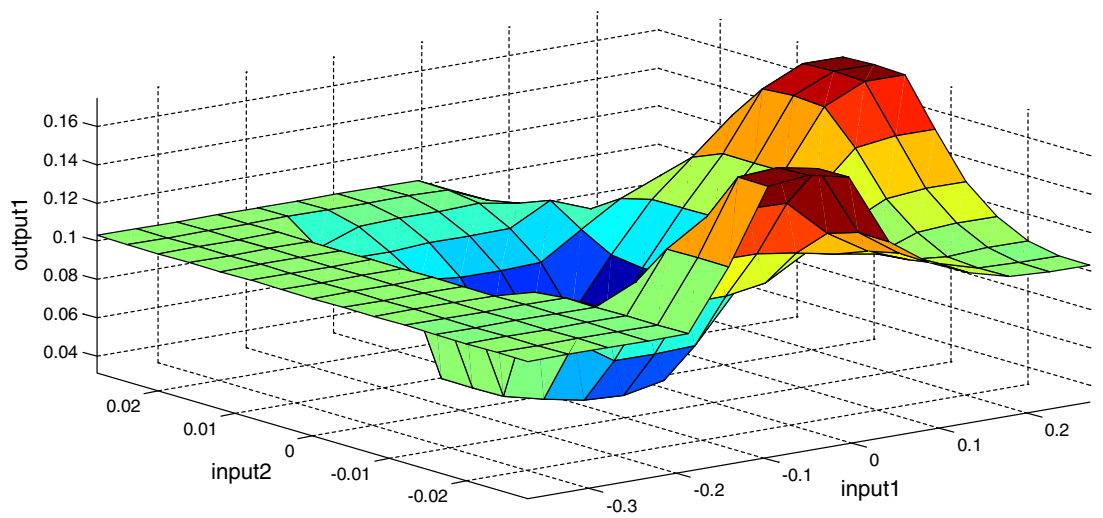

Fig. $63 \mathrm{D}$ plot of $S, S$ and $k_{f u z z y}$

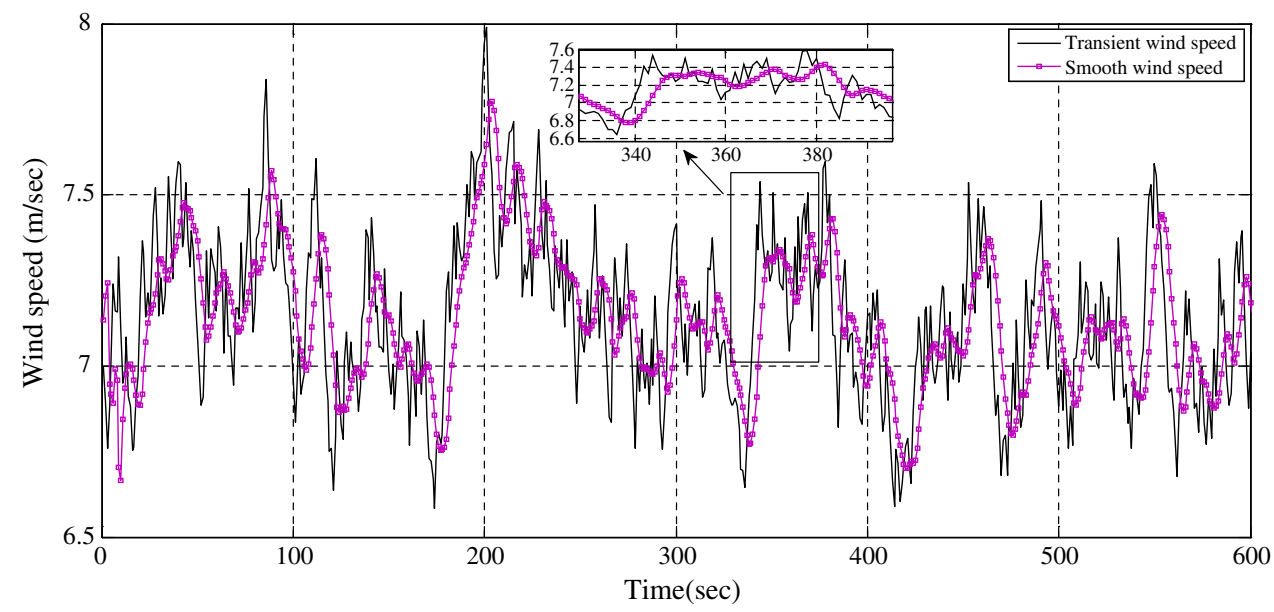

Fig. 7 Test wind speed profiles with a mean of $7 \mathrm{~m} / \mathrm{s}$ 


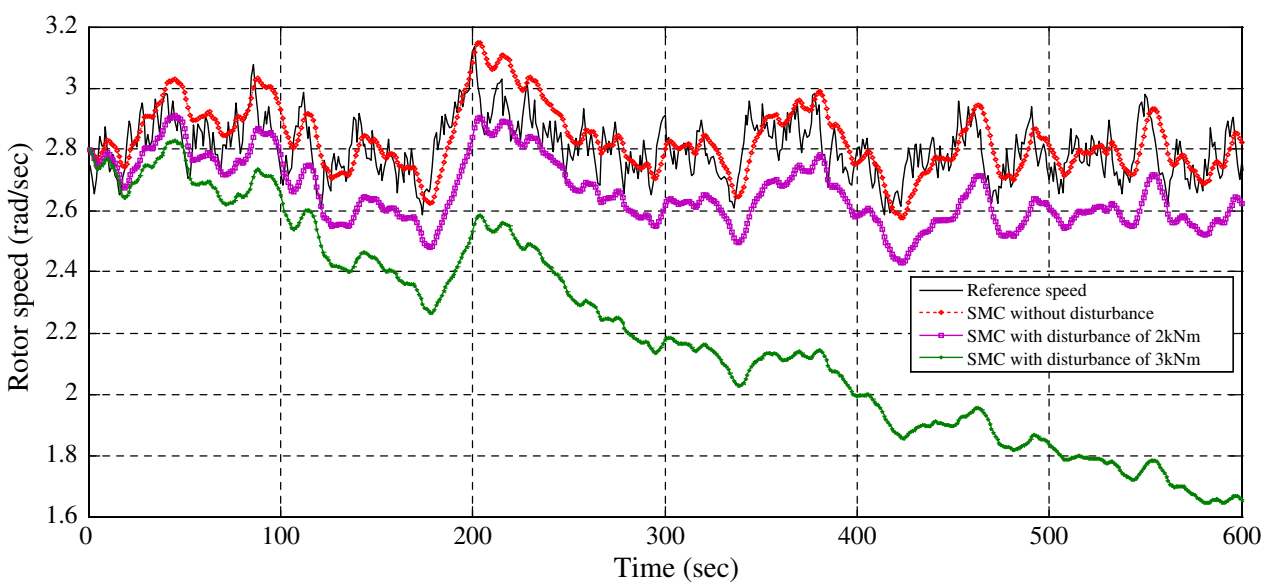

Fig. 8 Comparison of rotor speed with different disturbance for SMC (transient wind speed)

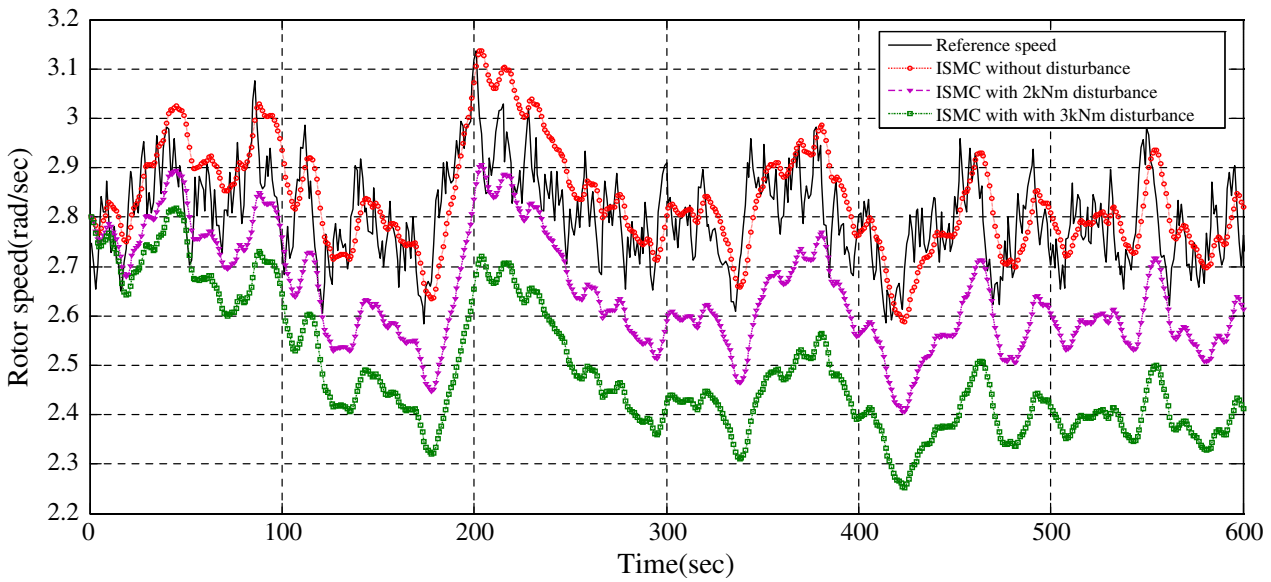

Fig. 9 Comparison of rotor speed with different disturbance for ISMC (transient wind speed)

\section{Results and discussion}

Figure 7 shows the test wind profile of the WT with mean wind speed of $7 \mathrm{~m} / \mathrm{s}$. Generally, wind speed consists of two components: mean and turbulent component. From this figure, it is clear that two different wind speeds are used with different turbulence intensity. Both the wind speeds are having $10 \mathrm{~min}$ wind data with the standard deviation (STD) of $0.25 \mathrm{~m} / \mathrm{s}$ (transient wind speed) and $0.19 \mathrm{~m} / \mathrm{s}$ (smooth wind speed). In order to analyze the robustness of the proposed AFISMC, three different input disturbances such as constant, sinusoidal and random disturbance of maximum magnitude $10 \mathrm{kNm}$ has been considered in this work.

Figures 8 and 9 show the rotor speed comparisons for SMC and ISMC considering both with and without input disturbances. From these figures, it is clear that without any input disturbance, the obtained rotor speed for SMC and ISMC are almost following the reference rotor speed. As shown in the Figs. 8 and 9, an increase in constant input disturbance level from 2 to $3 \mathrm{kNm}$ results a significant increase in tracking error due to which the rotor is unable to track the reference speed. This leads to more power loss and reduced electrical efficiency. The performances of the controllers are analyzed with respect to the following:

1) Aero dynamic and electrical efficiency

2) Maximum and standard deviation (STD) of control input

3) Controllers are tested with different wind profile.

4) Controllers are tested in presence of different level and types of input torque disturbance.

Figure 10 shows the rotor speed comparison for AFISMC with different level of constant input disturbances ranging from 2 to $7 \mathrm{kNm}$. Figures 11 and 12 shows the comparison of rotor speed and generator torque for AFISMC with different types of input disturbances such as constant, sinusoidal and random disturbances of magnitude $10 \mathrm{kNm}$. From Figs. 10 to 12 , it is observed that the 


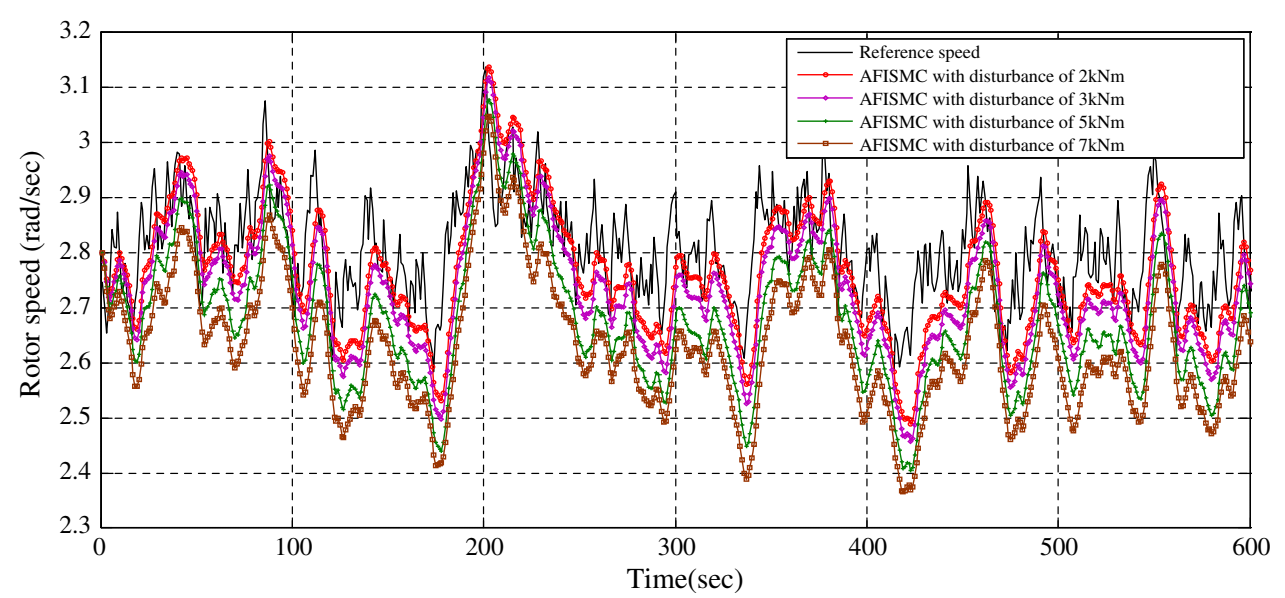

Fig. 10 Rotor speed comparisons for AFISMC with different level of constant disturbance (transient wind speed)

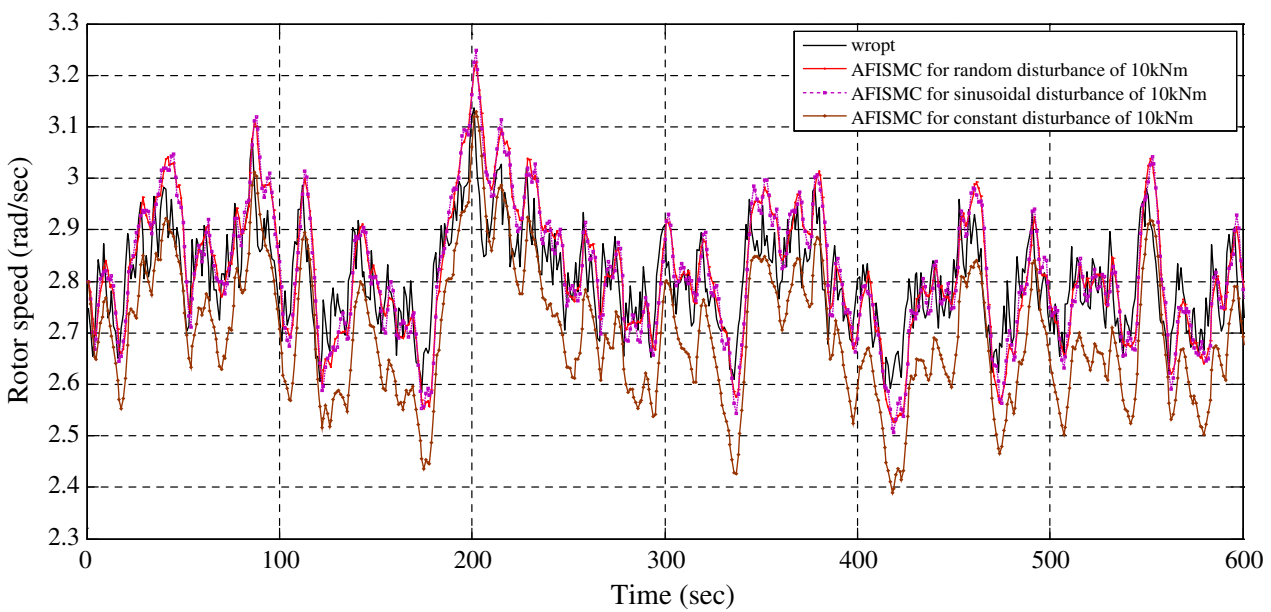

Fig. 11 Comparison of rotor speed with different disturbance for AFISMC (transient wind speed)

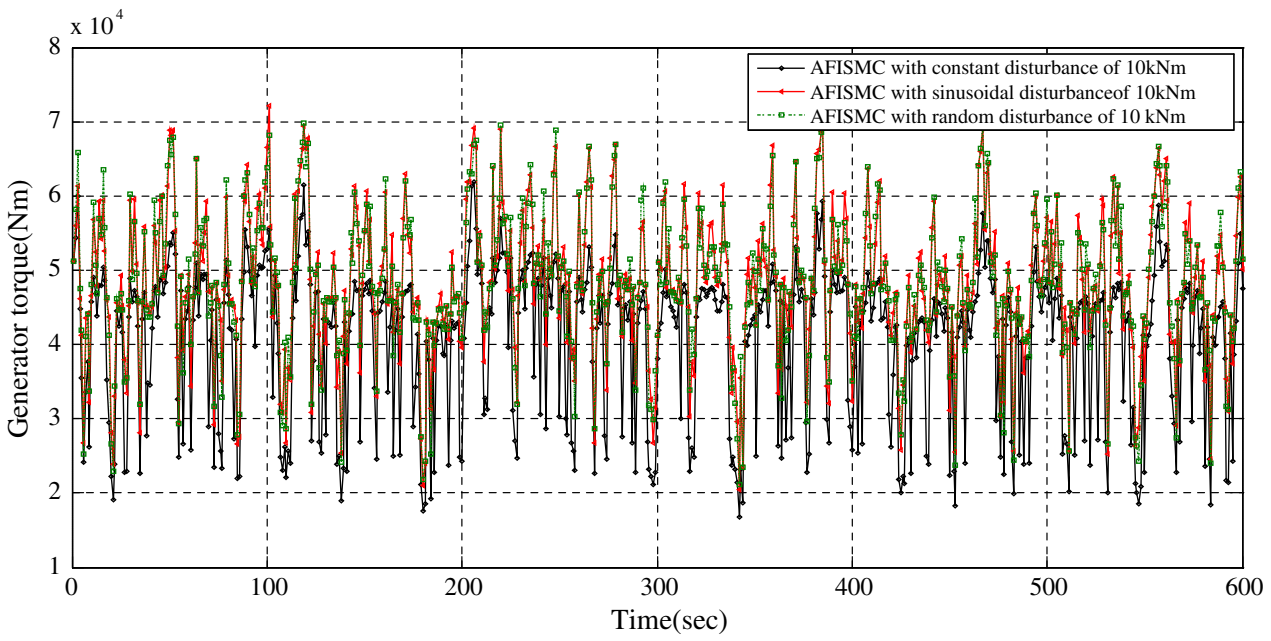

Fig. 12 Comparison of generator torque with different disturbance for AFISMC (transient wind speed) 
Table 3 Performance analysis of SMC with and without disturbances (wind speed $7 \mathrm{~m} / \mathrm{s}$ )

\begin{tabular}{llll}
\hline $\begin{array}{l}\text { SMC with and } \\
\text { without } \\
\text { disturbances }\end{array}$ & $\begin{array}{l}\text { SMC } \\
\text { without } \\
\text { disturbance }\end{array}$ & $\begin{array}{l}\text { SMC with } \\
\text { disturbance of } \\
2 \mathrm{kNm}\end{array}$ & $\begin{array}{l}\text { SMC with } \\
\text { disturbance of } \\
3 \mathrm{kNm}\end{array}$ \\
\hline $\begin{array}{l}\text { Max }\left(T_{g}\right) \mathrm{kNm} \\
\begin{array}{l}\text { Electrical } \\
\text { efficiency }(\%)\end{array}\end{array}$ & 51.92 & 55.20 & 61.44 \\
$\begin{array}{l}\text { Aerodynamic } \\
\text { efficiency }(\%)\end{array}$ & 93.23 & 89.50 & 81.17 \\
\begin{tabular}{l} 
STD $\left(T_{g}\right) \mathrm{kNm}$ \\
\hline
\end{tabular} & 1.928 & 1.705 & 85.82 \\
\hline
\end{tabular}

Table 4 Performance analysis of ISMC with and without disturbances (wind speed $7 \mathrm{~m} / \mathrm{s}$ )

\begin{tabular}{llll}
\hline $\begin{array}{l}\text { ISMC with and } \\
\text { without } \\
\text { disturbances }\end{array}$ & $\begin{array}{l}\text { ISMC } \\
\text { without } \\
\text { disturbance }\end{array}$ & $\begin{array}{l}\text { ISMC with } \\
\text { disturbance of } \\
2 \mathrm{kNm}\end{array}$ & $\begin{array}{l}\text { ISMC with } \\
\text { disturbance of } \\
3 \mathrm{kNm}\end{array}$ \\
\hline $\begin{array}{l}\text { Max }\left(T_{g}\right) \mathrm{kNm} \\
\begin{array}{l}\text { Electrical } \\
\text { efficiency }(\%)\end{array}\end{array}$ & 51.58 & 55.26 & 57.44 \\
$\begin{array}{c}\text { Aerodynamic } \\
\text { efficiency }(\%)\end{array}$ & 93.21 & 99.56 & 87.86 \\
\begin{tabular}{l} 
STD $\left(T_{g}\right) \mathrm{kNm}$ \\
\hline
\end{tabular} & 1.606 & 1.744 & 94.05 \\
\hline
\end{tabular}

Table 5 Performance analysis of AFISMC with and without disturbances ( $7 \mathrm{~m} / \mathrm{s}$ wind profile)

\begin{tabular}{llll}
\hline $\begin{array}{l}\text { AFISMC with } \\
\text { different types of } \\
\text { disturbances }(7 \mathrm{~m} / \mathrm{s} \\
\text { wind speed) }\end{array}$ & $\begin{array}{l}\text { AFISMC } \\
\text { with constant } \\
\text { disturbance } \\
\text { of } 10 \mathrm{kNm}\end{array}$ & $\begin{array}{l}\text { AFISMC with } \\
\text { sinusoidal } \\
\text { disturbance of } \\
10 \mathrm{kNm}\end{array}$ & $\begin{array}{l}\text { AFISMC } \\
\text { with random } \\
\text { disturbance } \\
\text { of } 10 \mathrm{kNm}\end{array}$ \\
\hline $\begin{array}{l}\text { Max }\left(T_{g}\right) \mathrm{kNm} \\
\begin{array}{l}\text { Electrical } \\
\text { efficiency }(\%)\end{array}\end{array}$ & 61.69 & 72.03 & 70.97 \\
$\begin{array}{c}\text { Aerodynamic } \\
\text { efficiency }(\%)\end{array}$ & 94.56 & 91.25 & 91.38 \\
\begin{tabular}{l} 
STD $\left(T_{g}\right) \mathrm{kNm}$ \\
\hline
\end{tabular} & 10.257 & 93.44 & 93.45 \\
\hline
\end{tabular}

performance of the WT with the proposed adaptive fuzzy based ISMC is able to track the maximum power delivery point in the presence of different types as well as the different level of input disturbances. Table 3 shows the performance of SMC as per the above mentioned criteria. From the results, it is clear that with an increase of disturbance level, the STD of the generated torque increases, which ensures more oscillation on the drive train. Also, it is found that the electrical and aerodynamic efficiency decreases with the increase in disturbance level, which introduces more power loss. Analyzing the results given in Table 3 and Fig. 8, it is concluded that conventional SMC is not robust to a disturbance level of more than $3 \mathrm{kNm}$.
Table 6 Performance analysis of AFISMC with and without disturbances $(8 \mathrm{~m} / \mathrm{s}$ wind profile)

\begin{tabular}{llll}
\hline $\begin{array}{l}\text { AFISMC with } \\
\text { different types of } \\
\text { disturbances }(8 \mathrm{~m} / \mathrm{s} \\
\text { wind speed) }\end{array}$ & $\begin{array}{l}\text { AFISMC } \\
\text { with constant } \\
\text { disturbance } \\
\text { of } 10 \mathrm{kNm}\end{array}$ & $\begin{array}{l}\text { AFISMC with } \\
\text { sinusoidal } \\
\text { disturbance of } \\
10 \mathrm{kNm}\end{array}$ & $\begin{array}{l}\text { AFISMC } \\
\text { with random } \\
\text { disturbance } \\
\text { of } 10 \mathrm{kNm}\end{array}$ \\
\hline $\begin{array}{l}\text { Max }\left(T_{g}\right) \mathrm{kNm} \\
\begin{array}{l}\text { Electrical } \\
\text { efficiency }(\%)\end{array}\end{array}$ & 71.56 & 67.93 & 80.00 \\
$\begin{array}{c}\text { Aerodynamic } \\
\text { efficiency }(\%)\end{array}$ & 93.27 & 89.31 & 89.39 \\
\begin{tabular}{l} 
STD $\left(T_{g}\right) \mathrm{kNm}$ \\
\hline
\end{tabular} & 9.289 & 91.88 & 91.88 \\
\hline
\end{tabular}

Table 7 Performance analysis of AFISMC with and without disturbances $(8.5 \mathrm{~m} / \mathrm{s}$ wind profile)

\begin{tabular}{llll}
\hline $\begin{array}{l}\text { AFISMC with } \\
\text { different types of } \\
\text { disturbances } \\
(8.5 \mathrm{~m} / \mathrm{s} \text { wind } \\
\text { speed })\end{array}$ & $\begin{array}{l}\text { AFISMC } \\
\text { with constant } \\
\text { disturbance } \\
\text { of } 10 \mathrm{kNm}\end{array}$ & $\begin{array}{l}\text { AFISMC with } \\
\text { sinusoidal } \\
\text { disturbance of } \\
10 \mathrm{kNm}\end{array}$ & $\begin{array}{l}\text { AFISMC } \\
\text { with random } \\
\text { disturbance } \\
\text { of } 10 \mathrm{kNm}\end{array}$ \\
\hline $\begin{array}{l}\text { Max }\left(T_{g}\right) \mathrm{kNm} \\
\begin{array}{l}\text { Electrical } \\
\text { efficiency }(\%)\end{array}\end{array}$ & 76.69 & 86.87 & 86.26 \\
$\begin{array}{c}\text { Aerodynamic } \\
\text { efficiency }(\%)\end{array}$ & 93.25 & 89.53 & 89.58 \\
\begin{tabular}{l} 
STD $\left(T_{g}\right) \mathrm{kNm}$ \\
\hline
\end{tabular} & 8.875 & 7.891 & 92.04 \\
\hline
\end{tabular}

Table 8 Analysis of electrical efficiency with respect to different level of disturbance for a wind speed of $7 \mathrm{~m} / \mathrm{s}$

\begin{tabular}{lllll}
\hline $\begin{array}{l}\text { AFISMC } \\
\text { with } \\
\text { disturbance }\end{array}$ & $\begin{array}{l}\text { AFISMC } \\
\text { with 2 kNm } \\
\text { disturbance }\end{array}$ & $\begin{array}{l}\text { AFISMC } \\
\text { with 3 kNm } \\
\text { disturbance }\end{array}$ & $\begin{array}{l}\text { AFISMC } \\
\text { with 5 kNm } \\
\text { disturbance }\end{array}$ & $\begin{array}{l}\text { AFISMC } \\
\text { with 7 kNm } \\
\text { disturbance }\end{array}$ \\
\hline $\begin{array}{l}\text { Electrical } \\
\text { efficiency } \\
(\%)\end{array}$ & 88.25 & 86.82 & 83.83 & 80.89 \\
$\begin{array}{l}\text { Mean } \\
\text { square } \\
\text { error }\end{array}$ & 0.008 & 0.011 & 0.023 & 0.037 \\
\hline
\end{tabular}

Table 4 shows the performance of ISMC in terms of efficiency and STD of input torque. This table ensures that an increase in disturbance level introduces more power loss and more drive train oscillation. It is observed that for ISMC, the WT is not able to track the reference rotor speed beyond the disturbance level of $3 \mathrm{kNm}$. For a disturbance level of $3 \mathrm{kNm}$, the electrical efficiency decreases to $87.86 \%$ for ISMC and $81.17 \%$ for SMC, which indicates that SMC and ISMC controllers are not robust with respect to disturbance of more than $3 \mathrm{kNm}$. Generally, WT system disturbance is not predictable and the controller should accommodate the disturbance with maximum power 


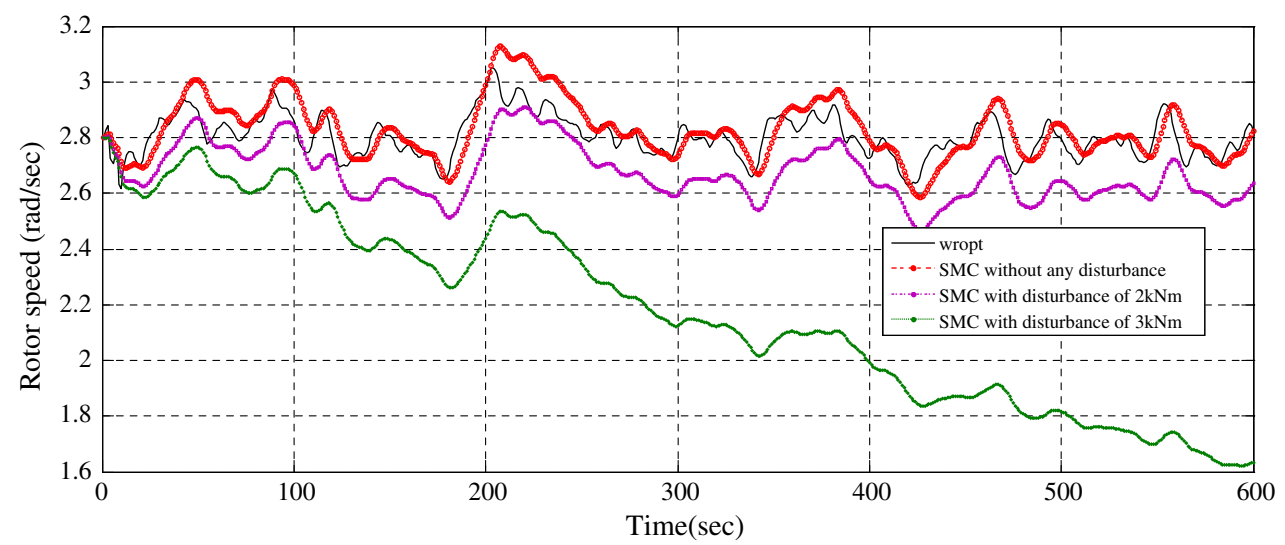

Fig. 13 Comparison of rotor speed with different disturbance for SMC (smooth wind speed)

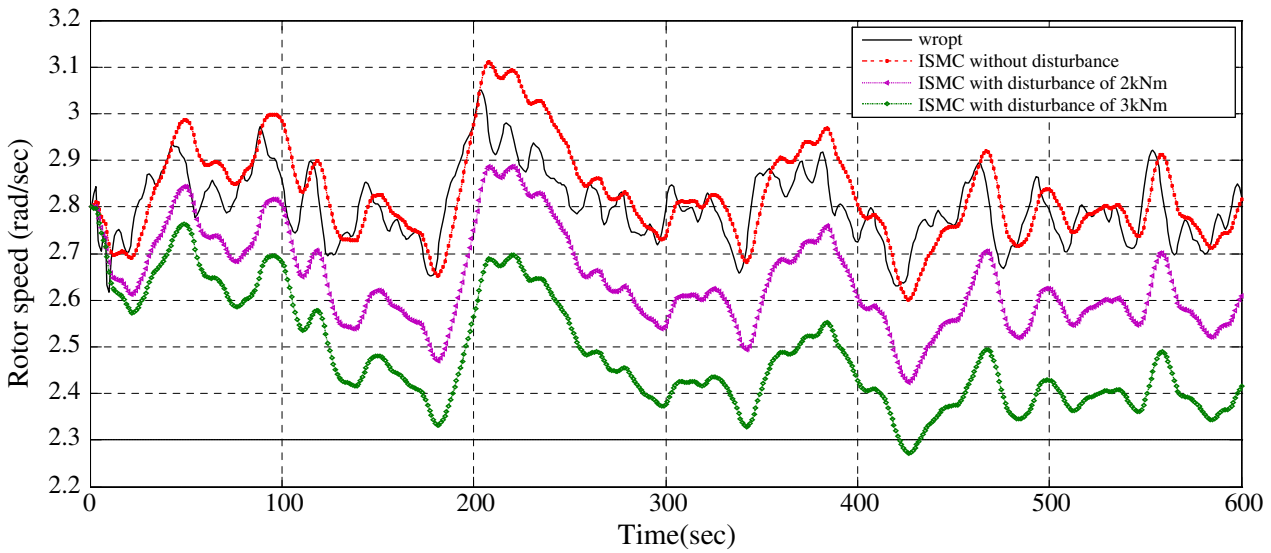

Fig. 14 Comparison of rotor speed with different disturbance for ISMC (smooth wind speed)

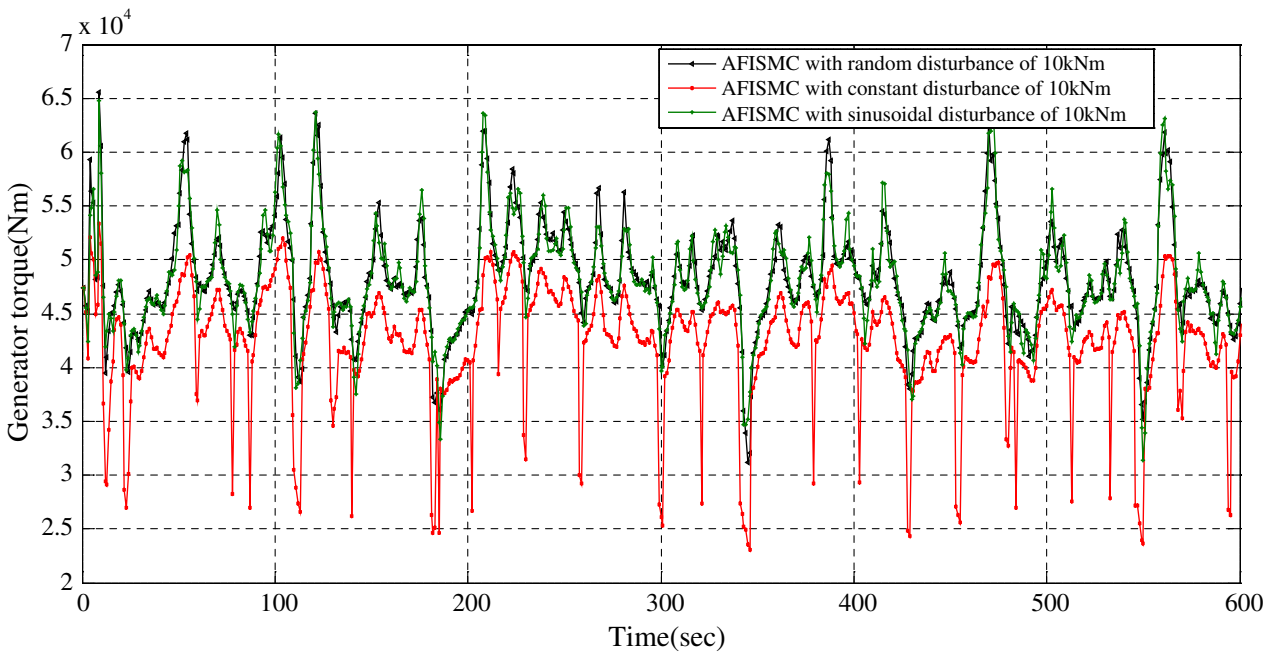

Fig. 15 Comparison of generator torque with different disturbance for AFISMC (smooth wind speed) 
Table 9 Performance analysis of SMC with and without disturbances for smooth wind speed of $7 \mathrm{~m} / \mathrm{s}$

\begin{tabular}{llll}
\hline $\begin{array}{l}\text { SMC with and without } \\
\text { disturbances (smooth } \\
\text { wind speed) }\end{array}$ & $\begin{array}{l}\text { SMC } \\
\text { without } \\
\text { disturbance }\end{array}$ & $\begin{array}{l}\text { SMC with } \\
\text { disturbance } \\
\text { of } 2 \mathrm{kNm}\end{array}$ & $\begin{array}{l}\text { SMC with } \\
\text { disturbance } \\
\text { of } 3 \mathrm{kNm}\end{array}$ \\
\hline $\begin{array}{l}\text { Max }\left(T_{g}\right) \mathrm{kNm} \\
\begin{array}{l}\text { Electrical efficiency } \\
(\%)\end{array}\end{array}$ & 51.82 & 53.29 & 60.97 \\
$\begin{array}{l}\text { Aerodynamic } \\
\text { efficiency }(\%)\end{array}$ & 93.34 & 94.74 & 80.64 \\
\begin{tabular}{l} 
STD $\left(T_{g}\right) \mathrm{kNm}$ \\
\hline
\end{tabular} & 1.77 & 1.423 & 85.23 \\
\hline
\end{tabular}

Table 10 Performance analysis of ISMC with and without disturbances for smooth wind speed of $7 \mathrm{~m} / \mathrm{s}$

\begin{tabular}{|c|c|c|c|}
\hline $\begin{array}{l}\text { ISMC with and } \\
\text { without disturbances } \\
\text { (smooth wind speed) }\end{array}$ & $\begin{array}{l}\text { ISMC } \\
\text { without } \\
\text { disturbance }\end{array}$ & $\begin{array}{l}\text { ISMC with } \\
\text { disturbance } \\
\text { of } 2 \mathrm{kNm}\end{array}$ & $\begin{array}{l}\text { ISMC with } \\
\text { disturbance } \\
\text { of } 3 \mathrm{kNm}\end{array}$ \\
\hline $\operatorname{Max}\left(T_{g}\right) \mathrm{kNm}$ & 51.12 & 54.11 & 56.91 \\
\hline $\begin{array}{l}\text { Electrical efficiency } \\
(\%)\end{array}$ & 91.15 & 89.61 & 87.94 \\
\hline $\begin{array}{l}\text { Aerodynamic } \\
\text { efficiency }(\%)\end{array}$ & 93.34 & 94.82 & 94.18 \\
\hline $\mathrm{STD}\left(T_{g}\right) \mathrm{kNm}$ & 1.388 & 1.482 & 1.865 \\
\hline
\end{tabular}

Table 11 Performance analysis of AFISMC with disturbances for smooth wind speed of $7 \mathrm{~m} / \mathrm{s}$

\begin{tabular}{llll}
\hline $\begin{array}{l}\text { AFISMC with } \\
\text { different types of } \\
\text { disturbances } \\
\text { (smooth wind } \\
\text { speed) }\end{array}$ & $\begin{array}{l}\text { AFISMC } \\
\text { with constant } \\
\text { disturbance } \\
\text { of } 10 \mathrm{kNm}\end{array}$ & $\begin{array}{l}\text { AFISMC with } \\
\text { sinusoidal } \\
\text { disturbance of } \\
10 \mathrm{kNm}\end{array}$ & $\begin{array}{l}\text { AFISMC } \\
\text { with random } \\
\text { disturbance } \\
\text { of } 10 \mathrm{kNm}\end{array}$ \\
\hline $\begin{array}{l}\text { Max }\left(T_{g}\right) \mathrm{kNm} \\
\begin{array}{l}\text { Electrical } \\
\text { efficiency }(\%)\end{array}\end{array}$ & 53.37 & 64.81 & 65.53 \\
$\begin{array}{c}\text { Aerodynamic } \\
\text { efficiency }(\%)\end{array}$ & 94.79 & 93.53 & 91.37 \\
STD $\left(T_{g}\right) \mathrm{kNm}$ & 5.612 & 4.814 & 93.53 \\
\hline
\end{tabular}

capture and reduced oscillation. Table 5 shows the performance of AFISMC with an objective of maximum energy extraction from the wind and reduced mechanical stress on the drive train. Different types of disturbances are given to the AFISMC controller: random, sinusoidal and constant disturbances with the magnitude of $10 \mathrm{kNm}$. From this table, it is clear that in the presence of $10 \mathrm{kNm}$ disturbance, the AFISMC is able track the reference rotor speed, whereas for SMC and ISMC, the WT is not able to track the reference for a disturbance level more than 3 $\mathrm{kNm}$.
The electrical and aerodynamic efficiency are almost found to be the same for sinusoidal and random disturbances, but with constant disturbance, the electrical efficiency is $18 \%$ less than the other two disturbances. From Tables 3, 4, and 5, it is concluded that SMC and ISMC are not robust to disturbances more than $3 \mathrm{kNm}$, but AFISMC is able to track the optimal rotor speed with different types of disturbances of magnitude $10 \mathrm{kNm}$.

In order to analyze the performance of the controllers critically, two different wind profiles are tested for simulation. The results for the mean wind speed of 8 and $8.5 \mathrm{~m} /$ $\mathrm{s}$ are given in Tables 6 and 7 respectively. Results given in the table can be analyzed in the same way as discussed in the previous sections. Finally, it is concluded that with increase in wind speed, there is an increase in electrical and aerodynamic efficiency, at the same time the oscillation in the drive train is reduced. Table 8 shows that, the increase in disturbance level decreases the efficiency of AFISMC. It can be observed that even though the efficiency decreases from $88.25 \%$ to $80.89 \%$, for a constant disturbance range of 2 to $7 \mathrm{kNm}$, the WT with AFISMC control is able to track the reference speed with minimum tracking error (mean square error) and maximum efficiency. In comparison with SMC and ISMC, the tracking error of AFISMC was found to be minimum with improved electrical efficiency.

Figures 13 and 14 show the rotor speed comparisons for SMC and ISMC with and without input disturbances, where a smooth variation in wind is considered. From these figures, it is clear that without any disturbance, the obtained rotor speed for SMC and ISMC are almost following the reference rotor speed. As shown in the Figs. 13 and 14, with an increase in input disturbance level from 2 to $3 \mathrm{kNm}$, there is a significant increase in tracking error due to which the rotor is unable to track the reference speed.

Figure 15 shows the comparisons of generator torque for AFISMC with different disturbances. Tables 9, 10, and 11 gives the performance of SMC, ISMC and the proposed AFISMC respectively for smooth wind speed of $7 \mathrm{~m} / \mathrm{s}$. The performance of the controller can be analyzed in the same way of analysis done for transient wind speed profile of $7 \mathrm{~m} / \mathrm{s}$. The only difference between two wind speed profiles is that, for a smooth variation of wind speed, the efficiency of the WT increases, at the same time, the STD of the input torque reduces. This indicates a smooth variation in generated torque for a smooth varying wind speed.

\section{Conclusions}

Extracting maximum power at below rated wind speed is an important component of efficiently harnessing wind power. Selection of the right control strategy is therefore 
important to ensure that the system performs optimally. The objective is to design robust controllers that maximize the energy extracted from the wind while reducing transient loads on the drive train. To achieve the above objective, nonlinear controllers such as SMC and ISMC are adapted initially to control a single mass model of the WT of $600 \mathrm{~kW}$ machine. Those controllers are found to give weak performance particularly in the presence of input torque disturbance of more than $3 \mathrm{kNm}$. In this work, a nonlinear AFISMC with MNR wind speed estimator has been developed. The proposed controller is a combination of fuzzy technique, and the ISMC where the discontinuity in ISMC is smoothed by using hyperbolic tangent function, and the sliding gain is adapted using a fuzzy technique which makes the controller more robust. Compared to SMC and ISMC, the proposed AFISMC is found to be more robust in achieving the above objectives in the presence of input torque disturbance varying from 2 to $10 \mathrm{kNm}$. To prove the efficiency of the proposed AFISMC control, the simulation has been conducted for different wind speed profiles with different turbulence component.

Open Access This article is distributed under the terms of the Creative Commons Attribution License which permits any use, distribution, and reproduction in any medium, provided the original author(s) and the source are credited.

\section{References}

[1] Carlin PW, Laxson S, Muljadi EB (2010) The history and state of the art of variable-speed wind turbine technology. Wind Energy 6(2):129-159

[2] Wang Q, Chang L (2004) An intelligent maximum power extraction algorithm for inverter-based variable speed wind turbine systems. IEEE Trans Power Electron 19(5):1242-1249

[3] Simoes MG, Bose BK, Spiegel RJ (1997) Fuzzy logic based intelligent control of a variable speed cage machine wind generation system. IEEE Trans Power Electron 12(1):87-95

[4] Eltamaly AM, Farh HM (2013) Maximum power extraction from wind energy system based on fuzzy logic control. Electro Power Syst 97(19):144-150

[5] Østergaard KZ, Brath P, Stoustrup J (2007) Estimation of effective wind speed. J Phys Conf Ser 75:1-9

[6] Boukhezzar B, Siguerdidjane H (2005) Nonlinear control of variable speed wind turbines without wind speed measurement. In: Proceedings of the IEEE conference on decision and control (CDE-ECC ‘05), 12-15 Dec 2005, pp 3456-3461
[7] Boukhezzar B, Siguerdidjane H, Hand MM (2006) Nonlinear control of variable-speed wind turbines for generator torque limiting and power optimization. J Sol Energy Eng 128(4):516-530

[8] Boukhezzar B, Siguerdidjane H (2011) Nonlinear control of a variable-speed wind turbine using a two-mass model. IEEE Trans Energy Convers 26(1):149-162

[9] Ćirić I, Ćojbašić Z, Vlastimir N et al (2011) Hybrid fuzzy control strategies for variable speed wind turbines. Facta Universitatis $10: 205-217$

[10] Beltran B, Ahmed-ali T, Bensouzid MEH (2008) Sliding mode power control of variable speed wind energy conversion systems. IEEE Trans Energy Conv 23(2):551-558

[11] Beltran B, Ahmed-ali T, BeNSouzid MEH (2009) High-order sliding-mode control of variable speed wind turbines. IEEE Trans Ind Electron 56(9):3314-3321

[12] Merabet A, Beguenane R, Thongam Jogendra ST et al (2011) Adaptive sliding mode speed control for wind turbine systems. In: Proceedings of the 37th Annual Conference on IEEE Industrial Electronics Society (IECON '11), 7-10 Nov 2011, pp 2461-2466

[13] Ben-Tzvi P, Bai S, Zhou Q et al (2011) Fuzzy sliding mode control of rigid-flexible multibody systems with bounded inputs. J Dyn Syst Meas Control 133(6):061012

[14] Eker I, Akinal SA (2005) Sliding mode control with integral action and experimental application to an electromechnical system. In: Proceedings of the international conference on computational intelligence methods and application (ICSC '05), Turkey, pp 1-6

[15] Boukezzar B, M'Saad M (2008) Robust Sliding mode control of a DFIG variable speed wind turbine for power production optimization. In: Proceedings of the 16th Mediterranean conference on control and automation, Ajaccia, France, 25-27 June, pp 795-800

Saravanakumar RAJENDRAN received the Master degree in Electrical Engineering from Anna University, Coimbatore Region, India, in 2010. Currently, he is pursuing the Ph.D. degree in the Department of Electrical \& Electronics Engineering, National Institute of Technology Karnataka, Surathkal, India.

Debashisha JENA received his Bachelor degree of Electrical Engineering degree from University College of Engineering, Burla, India, in 1996. He received Master degree of Engineering in Power System in 2004 and Ph.D. degree in Control System Engineering from the Department of Electrical Engineering, National Institute of Technology, Rourkela, India in 2010. He was awarded a GSEP fellowship in 2009 from Canada for research on neuro control of complex dynamic systems. Currently, he is an Assistant Professor in the Department of Electrical \& Electronics Engineering in the National Institute of Technology Karnataka, Surathkal, Mangalore, India. His research interests include evolutionary computation, system identification and neuro-evolutionary computation, and its application to distributed generation. 